\title{
Time for a fresh start
}

\author{
Fifty years after the momentous launch of Sputnik, Russia has yet to find a scientific system \\ that is anything close to meeting its twenty-first century needs.
}

T he launch of the Sputnik probe on board an R-7 rocket on Friday 4 October 1957 can be seen, in retrospect, as the former Soviet Union's finest hour. It was the point at which that nation's alleged devotion to science and technology found its ultimate symbolic triumph.

But the awe that the launch inspired around the world (see page 538) proved to be short-lived. The country's centralized system for managing science and technology was subsequently impaled, as the Marxists would put it, on its own contradictions.

Sixteen years after the Soviet Union ceased to exist, science in Russia has yet to fully discard the baggage it inherited from the Soviet era (see pages 524 and 528). If anything, after several faltering attempts at reform, the Russian Academy of Sciences is retreating into its sclerotic past.

As recently as the 1980s, according to most estimates, the Soviet Union had more scientists and engineers than the United States. Isolated as they were from contemporaries in much of the rest of the world, these researchers clocked up a number of noteworthy achievements, in spheres ranging from rocket technology to pure mathematics. But even at the time Sputnik took off, the writing was on the wall for Soviet scientific advancement: the politically inspired aversion to the study of genetics, implemented by Trofim Lysenko, director of Soviet biology under Joseph Stalin, was in itself sufficient to ensure that many of the major scientific advances of the second half of the twentieth century would take place with little or no Soviet involvement.

Indeed, the success of Sputnik arguably accelerated the relative decline of Soviet science and technology by creating a massive impetus for the state sponsorship of both in the United States and elsewhere (see page 542).

\section{After the fall}

But the scientific community within the Soviet Union retained an influential and relatively comfortable position until the union's collapse in 1991. Given the speed at which events unfolded, it is hardly surprising that scientists were unprepared for the sudden end of a political system that they had occasionally criticized, but that had fed them well. Abandoned by the government, and unable to come to terms with the reforming frenzy in the early days of capitalism, Russia's scientific élite, in particular, saw the end of communism as a kind of existential threat. But it is disappointing and surprising that even now resentment, bitterness and attempts to defend old privileges are still widespread among Russian professors.

The same is true, on an institutional level, for the Russian Academy of Sciences - now, as then, the backbone of the country's research system. The academy's measurable scientific output is in decline, and yet many (perhaps most) of its members are stubbornly opposing all proposals for reform, whether they emanate from the academy itself or from Vladimir Putin's government.

The academy's autonomy is threatened by a 2006 decree from Putin that would give him the power of veto over its elected presidency. But to protect itself effectively, the academy needs to reinvent itself as a strong, modern institution, whose values are worth defending (see page 536). Clinging to past glories just won't do. The Russian government is increasingly unwilling to tolerate the academy's never-ending dodging and manoeuvring when it comes to the introduction of performancerelated funding mechanisms, more competition and increased accountability.

The catastrophic funding situation of a decade ago, when many institutes survived thanks only to foreign aid, is not the sole reason for the academy's current ills. It has neglected to adopt quality standards that all successful science nations consider vital for achieving what is commonly called 'excellence'.

\section{Lack of perspective}

Getting scientific papers published in international journals, for example, is essential for researchers from Boston to Beijing. But at most Russian institutes no one cares about publication lists and impact factors, and many scientists regard as impertinent the idea that research careers should depend on papers in 'foreign' journals. The very notion of peer review is still not accepted by the old guard.

All this must change. The academy needs to make sure that the limited funds are being allocated, in a competitive and transparent way, to the best groups and projects in each field. This is even more important now that public research spending is increasing, thanks to Russia's booming economy. But in the absence of real competition and stringent quality-management the extra money is likely to dissolve in nepotism and ill-reviewed projects.

A thorough evaluation of all academy institutes, by respected scientists from Russia and abroad, would be the best way to commence modernization. Further neglect of reform will cement only the academy's decline into mediocrity or obsolescence, and foster yet more emigration of young talent. The academy should instigate this process before it has a more draconian one thrust upon it by the Kremlin.

There is no need for Russia to uncritically copy 'the' Western science system. There are, in fact, many such systems in operation, ranging from the single-grant system that predominates in the United States to the French approach of supporting most research under contracts between the government and a network of permanently staffed research institutions. Given its own scientific tradition and circumstances, the latter may suit Russia better. But the failure to modernize thus far suggests that it will be many years before Russian science and technology again holds the world in awe. 